\title{
DESKRIPSI PELAYANAN KESEHATAN (INSTALASI FARMASI) DI RSUD PROF. DR. H. ALOEI SABOE KOTA GORONTALO
}

\section{HEALTH SERVICES DESCRIPTION (Pharmacy Installation) IN DISTRICT HOSPITAL PROF. DR. H. ALOEI SABOE GORONTALO CITY}

\author{
Dede Sutriono $^{1 *}$, Sudirman ${ }^{2}$ \\ ${ }^{1}$ Program Studi Magister Administrasi Publik, Pasca Sarajana STIA Bina Taruna Gorontalo \\ ${ }^{2}$ Lembaga Penelitian dan Pengabdian Kepada Masyarakat, Universitas Bina Mandiri \\ *email: ddsutrio@gmail.com
}

\begin{abstract}
Improving the service quality system in the hospital will certainly create and provide satisfaction to customers. Measurement of service quality is very important, especially in improving service quality with the aim that the provider gets loyal customers. Therefore, the purpose of this study was to describe the quality of service at the Pharmacy Installation of Prof. Dr. H. Aloei Saboe, Gorontalo City. This research is a qualitative descriptive type with a case study approach in September-October 2019 at the Pharmacy Installation. The informants of this study were 5 health workers who were registered as pharmacy staff at Prof. Dr. H. Aloei Saboe, and 5 patients selected based on accidental sampling technique. Data analysis uses ISI analysis, then displays it in the form of narrative text. The results showed that: (1) The quality of health services in the Pharmacy Installation of Prof. Dr. H. Aloei Saboe, Gorontalo City in tangible and empathy dimensions showed unsatisfactory results where the lack of infrastructure and utilization was not optimal. Dimensions of reliability, responsiveness and assurance of service quality provided to the patient/patient's family are in accordance with customer standards and expectations and are categorized as good. (2) Factors for supporting infrastructure in the waiting room of the installation are still very minimal, as well as the rooms that are still less representative, besides that the human resources on duty at the Pharmacy Installation do not match the qualifications so that patient/patient family satisfaction is not fulfilled. It can be concluded that the Pharmacy Installation is still considered lacking by the customer so that it is necessary to improve the quality of service in the tangible and empathic dimensions.
\end{abstract}

Keywords: Health Service Quality, Pharmacy Installation, Patient Satisfaction.

\begin{abstract}
Abstrak
Peningakatan sistem kualitas layanan di rumah sakit tentunya akan dapat menciptakan serta memberikan kepuasan terhadap pelanggan. Pengukuran terhadap kualitas pelayanan menjadi sangat penting khususnya dalam meningkatkan kualitas pelayanan dengan tujuan bahwa penyedia mendapatkan pelanggan yang setia. Oleh karena itu, tujuan dari penelitian ini adalah untuk mendeskripsikan kualitas pelayanan di Instalasi Farmasi RSUD Prof. Dr. H. Aloei Saboe Kota Gorontalo. Penelitian ini berjenis deskriptif kualitatif dengan pendekatan studi kasus pada Bulan September-Oktober 2019 di Instalasi Farmasi. Informan penelitian ini berjumlah 5 orang tenaga kesehatan yang berada dan tercatat sebagai pegawai farmasi RSUD Prof. Dr. H. Aloei Saboe, dan 5 orang pasien yang dipilih berdasarkan teknik accidental sampling. Analisis data menggunakan analisis ISI, kemudian menampilkannya dalam bentuk teks naratif. Hasil penelitian menunjukkan bahwa: (1) Kualitas pelayanan kesehatan di Instalasi Farmasi RSUD Prof Dr. H. Aloei Saboe Kota Gorontalo pada dimensi tangible dan empathy menunjukkan hasil yang kurang memuaskan dimana minimnya sarana prasaran serta pemanfaatannya yang belum maksimal. Dimensi reliability, responsiveness dan assurance kualitas pelayanan yang diberikan kepada pasien/keluarga pasien sudah sesuai dengan standar dan harapan pelanggan dan dikategorikan baik. (2) Faktor sarana prasarana penunjang di ruang tunggu instalasi masih sangat minim, serta ruangan yang masih kurang representatif, selain itu juga SDM yang bertugas di Instalasi Farmasi yang belum sesuai kualifikasi sehingga kepuasan pasien/keluarga pasien tidak terpenuhi. Dapat di simpulkan bahwa
\end{abstract}


Instalasi Farmasi masih dipandang kurang oleh customer sehingga perlu untuk meningkatkan kualitas pelayanan pada dimensi tangible dan empathy.

Kata kunci: Kualitas Pelayanan Kesehatan, Instalasi Farmasi, Kepuasan Pasien.

\section{PENDAHULUAN}

Rumah sakit dibangun pada dasarnya memberikan pelayanan kesehatan kepada pasien seperti halnya industri jasa lainnya. Salah satu syarat faktor utama agar rumah sakit dapat berlangsung yaitu apabila mampu memberi pelayanan kesehatan yang prima serta menghasilkan kepuasan terhadap pelanggannya. Masyarakat yang puas dalam pelayanan rumah sakit akan cenderung mematuhi rencana standar pelayanan pengobatan yang diberikan, namun sebaliknya jika masyarakat yang kurang puas cenderung tidak mematuhi dan hal terburuk pastinya akan berganti ke fasilitas pelayanan kesehatan lain atau rumah sakit lain (Azwar, 2015).

Tuntutan pelanggan terhadap berbagai aspek dalam pelayanan di rumah sakit semakin meningkat dengan berlakunya perindustrian saat ini. Peningakatan sistem kualitas layanan di rumah sakit tentunya akan dapat menciptakan serta memberikan kepuasan terhadap pelanggan. Kualitas pelayanan di Rumah Sakit tentunya harus dimulai dari kebutuhan pasien serta berakhir pada persepsi atau penilaian pasien. Oleh karena itu, kualitas layanan yang baik bukan hanya dilihat dari segi persepsi atau penilaian penyedia jasa itu sendiri, melainkan berdasarkan persepsi pasien/pelanggan/ customer.

Pengukuran terhadap kualitas pelayanan menjadi sangat penting khususnya dalam meningkatkan kualitas pelayanan dengan tujuan bahwa penyedia mendapatkan pelanggan/ customer yang setia. Dalam hal keuntungan yang sebenarnya bukan datang dari pelanggan yang puas saja, melainkan dari pelanggan yang setia. Pemberian kualitas pelayanan kesehatan yang buruk dan mengecewakan pelanggan/ customer merupakan beberapa sebab dari kurang baiknya sistem yang dibangun. Sehingga untuk memenuhi keperluan dan kebutuhan pasien serta berusaha menjaga pelanggan merupakan keutamaan dari organisasi kesehatan, (Hidayatullah, 2010).

Rumah sakit yang merupakan bagian dari layanan publik yang diatur dalam UndangUndang Nomor 44 Tahun 2009 tentang Rumah Sakit. Dalam rangka meningkatkan mutu dan jangkauan pelayanan, rumah sakit harus mampu mewujudkan kesehatan masyarakat yang setinggi-tingginya. Pada pasal pasal 4 mengenai tugas dan fungsi rumah sakit dijelaskan bahwa rumah sakit mempunyai tugas dalam memberikan pelayanan kesehatan perorangan secara paripurna. Selaras dengan standar prosedur farmasi di rumah sakit berdasarkan keputusan Menteri Kesehatan Nomor 1197/MENKES/SK/X/2004 bahwa pelayanan farmasi yang berorientasi pada pasien demi terwujudnya pelayanan yang efektif dan efisien.

Rumah Sakit Umum Daerah (RSUD) Prof. Dr. H. Aloei Saboe di Provinsi Gorontalo berstatus sebagai Rumah Sakit kelas B berdasarkan Surat Keputusan Menteri Kesehatan Nomor 084/MENKES/SK/I/2009, memiliki peran strategis dan sangat penting dalam memberikan pelayanan kesehatan bagi masyarakat Kota Gorontalo dan sekitarnya. Kualitas layanan kesehatan yang dimaksud tentunya memberikan layanan publik yang sesuai dengan persyaratan perundang-undangan. Dalam sebuah produk jasa seperti rumah sakit, persepsi pasien terhadap kualitas pelayanan merupakan suatu penilaian yang menyeluruh. Kualitas jasa ditentukan semata-mata oleh pasien sehingga kepuasan pasien dapat tercapai dengan memberikan kualitas pelayanan yang baik (Fahmi, A. 2014).

Berdasarkan hasil observasi yang dilakukan oleh peneliti pada tanggal 27-29 Agustus 2019 pada Instalasi Farmasi RSUD Prof. Dr. H. Aloei Saboe Kota Gorontalo, ditemukan informasi dari 3 informan bahwa: (1) terdapat malfungsi sarana prasarana penunjang diruang tunggu. (2) Ruang tunggu yang kurang kondusif dengan keadaan yang panas dan sesak. (3) Seringnya terjadi keliruan oleh petugas di instalasi farmasi dalam menerapkan SOP seperti over time waiting dan

kurang menunjukkan rasa empati dan simpati kepada pasien. Hal tersebut berdampak pada ketidakpuasan dan ketidak senangan yang dirasakan oleh setiap pasien. Hal tersebut juga tidak sejalan dengan Undang-Undang nomor 44 tahun 2009 pasal 4 yang menjelaskan bahwa rumah sakit mempunyai tugas dalam memberikan pelayanan kesehatan perorangan secara paripurna dan Keputusan Menteri Kesehatan nomor 1197/MENKES/SK/X/2004 
bahwa pelayanan farmasi yang berorientasi pada pasien demi terwujudnya pelayanan yang efektif dan efisien.

\section{METODE PENELITIAN}

Penelitian ini menggunakan metode kualitatif dengan pendekatan studi kasus. Penelitian ini dilakukan pada Bulan September hingga Oktober 2019 Di Instalasi Farmasi RSUD Prof. dr. H. Aloei Saboe Kota Gorontalo. Informan dalam penelitian ini adalah semua tenaga kesehatan yang berada dan tercatat sebagai pegawai farmasi RSUD Prof. dr. H. Aloei Saboe yang di tempatkan pada instalasi farmasi berjumlah 5 orang dan 5 orang informan pasien yang diambil dengan teknik accidental sampling. Pengumpulan data informasi menggunakan pendekatan wawancara mendalam kepada sampel informan. Analisis data menggunakan analisis ISI untuk menarik kesimpulan dengan mengurangi data, kemudian menampilkannya dalam bentuk teks naratif dengan menggunakan fakta yang diperoleh di lapangan. Penelitian ini bertujuan untuk mendeskripsikan kualitas pelayanan di Instalasi Farmasi RSUD Prof. Dr. H. Aloei Saboe Kota Gorontalo.

\section{HASIL PENELITIAN}

RSUD Prof. Dr. H. Aloei Saboe Kota Gorontalo memiliki tugas pokok dan fungsi sesuai pada Peraturan Walikota Gorontalo Nomor 24 Tahun 2008, yaitu dengan tugas pokok melaksanakan sebagian dari tugas pemerintah dan pembangunan dibidang pelayanan kesehatan, bidang keperawatan, bidang umum kepegawaian bidang perencanaan dan bidang keuangan. Fungsi RSUD Prof. Dr. H. Aloei Saboe Kota Gorontalo meliputi: (1) pelayanan medis. (2) Pelayanan penunjang medis dan non medis. (3) Pelayanan dan asuhan keperawatan. (4) Pelayanan rujukan. (5) Pendidikan dan pelatihan. (6) Penelitian dan pengembangan. (7) Pelayanan administrasi umum dan pengembangan. Semenjak berdirinya RSUD Prof. Dr. H. Aloei Saboe telah terjadi beberapa kali perubahan kepemimpinan.

\section{Karakteristik Informan}

Informan penelitian berjumlah 10 orang yang terdiri dari 5 orang petugas kesehatan di Instalasi Farmasi RSUD Prof. dr. H. Aloei Saboe, Kota Gorontalo. Rata-rata umur informan pada Instalasi Farmasi antara 27 sampai dengan 36 tahun dengan jenjang pendidikan diploma (Amd. farm) hingga strata satu (S.Farma). Sedangkan pada informan pasien,umur rata-rata antara 24 sampai dengan 52 tahun dengan jenjang pendidikan Sekolah Menengah Pertama (SMP) hingga Strata 2 (Magister).

Tabel 1. Kepemimpinan RSUD Prof. Dr. H. Aloei Saboe sejak 1929-2020

\begin{tabular}{ll}
\hline Nama & Periode Jabatan \\
\hline Prof. Dr. H. Aloei Saboe & Tahun 1929-1951 \\
Dr. Lim Tang Hong & Tahun 1951 \\
Dr. Teksan & Tahun 1972 \\
Dr. Nicartin Pakaya & Tahun 1972-1974 \\
Dr. Hudaya Sudarman & Tahun 1974-1978 \\
Dr. Nicartin Pakaya & Tahun 1974-1979 \\
Dr. Abdul Latif Hiola & Tahun 1979-1983 \\
Dr. Hi. Rahman H. Pakaja & Tahun 1983-1997 \\
Dr. T.D.E Abeng & Tahun 1997-1998 \\
Dr. Hi. A. Tolohula & Tahun 1998-1999 \\
Dr. H. Sudirman Muhammad & Tahun 1999-2004 \\
Dr. Hj. Nurinda Rahim, & Tahun 2004-2010 \\
M.Sc. & \\
Dr. Andang Ilato, MM & Tahun 2010- \\
& sekarang \\
\hline
\end{tabular}

Sumber: Laporan RSUD Aloei Saboe Tahun 2019.

\section{Dimensi Tangible (Bukti Fisik)}

Hasil wawancara mendalam terhadap petugas Instalasi Farmasi terkait dimensi tangible (bukti fisik) dengan pertanyaan tentang alur pelayanan pengambilan obat, kebersihan ruang tunggu, luas ruangan, dan ketersediaan sarana penunjang, yaitu:

"Pada dasarnya bahwa rumah sakit memiliki standar pelayanan, ini merupakan standar pelayanan yang telah ditetapkan melalui Permenkes yang dari peraturan tersebut di turunkan menjadi

SOP, serta SOP ini hukumnya wajib ada dan dilaksanakan oleh dan sebagai acuan. Selain itu bahwa beberapa bukti fisik yang ada memang tidak berfungsi seperti TV LED yang seharusnya

berfungsi untuk memberikan informasi kepada keluarga pasien, namun kami sadari bahwa TV LED tersebut telah trouble”. (A.H.P - Hasil Wawancara Tanggal 12 November 2019).

Berdasarkan hasil wawancara mendalam terhadap keluarga pasien, pada dimensi tangible (bukti fisik) dengan pertanyaan tentang alur pelayanan pengambilan obat, kebersihan ruang tunggu, luas ruangan dan ketersediaan sarana penunjang, menunjukkan bahwa:

"Menurut saya bahwa di Instalasi Farmasi Rumah Sakit Prof. Dr. H. Aloei Saboe memang terdapat alur informasi pelayanan obat, serta kondisinya bersih. Dalam hal alur tersebut tidak dijelaskan kepada keluarga pasien, padahal baiknya adalah 
memberikan informasi tersebut kepada keluarga pasien sehingga kami bisa memahami jika ada suatu saat keterlambatan dalam pengambilan obat, selain itu juga bahwa sebenarnya di instalasi farmasi terdapat sound sistem namun kualitas suaranya kurang bagus kadang-kadang suaranya kecil. Pada bagian ruang tunggu juga sebenarnya terdapat TV LED yang terpasang namun tidak menyala. Dengan melihat kondisi tersebut menurut saya selaku keluarga pasien harusnya lembaga harus memberikan pelayanan yang baik khususnya di ruang tunggu harus diberikan fasilitas yang memadai misalnya seperti colokan Hand Phone, air minum, serta kipas angin karena kita ketahui secara bersama ruang tunggu Instalasi Farmasi

Rumah Sakit Prof. Dr. H. Aloei Saboe dibuat terbuka dan begitu terasa panas". (W.I, R.Z dan I.Y - Hasil wawancara pada tanggal 12 November 2019, Pukul 10.15 WITA)

Informasi yang berbeda diberikan oleh informan R.O saat diwawancarai mengenai bukti fisik, yaitu:

"Menurut saya sebagai keluarga pasien rawat inap setiap kali mengambil obat melihat bahwa, aspek fisik Instalasi Farmasi sudah sangat nyaman, bagus, dan rapi. Bahkan di ruang instalasi terdapat alur pelayanan obat sehingga ini memudahkan keluarga pasien untuk mengetahui alur saat mengambil obat. Selain itu juga bahwa keadaan tersebut bersih karena saya melihat banyak cleaning service yang membersihkan ruangan tersebut, jadi walaupun menunggu lama karena bersih kita tetap nyaman.

Aspek ini juga mungkin karena saat saya mengantre masih pagi jadi kelihatannya rapi dan bersih". (Hasil wawancara tanggal 11 November 2019).

\section{Dimensi Realibility}

Hasil wawancara yang dilakukan terhadap informan, mengenai keandalan petugas instalasi farmasi RSUD Prof. Dr. H. Aloei Saboe ditinjau dari aspek pertanyaan tentang: (1) kemudahan petugas untuk ditemui dan dihubungi. (2) Kecepatan dalam memberikan pelayanan, dan (3) penjelasan petugas mengenai DAGUSIBUdiantanya adalah sebagai berikut:

"Petugas pada umumnya mudah ditemui dan dihubungi karena memang petugas berada di loket Instalasi Farmasi. Hanya saja dalam segi pelayanan pengambilan obat, saat resep dimasukkan, waktu menunggunya cukup lama, padahal kalau dilihat maksimal paling lama 60 menit berdasarkan standar yang ditempel, namun faktanya lebih dari itu. Mungkin karena petugasnya sedikit, selain itu juga menurut saya kenapa jadi lama karena loket yang dibuka hanya satu loket. Resep obat diberikan petugas tidak memberitahukan penggunaan obat (DaGuSiBu) secara lengkap, petugas hanya memberitahukan cara mengkonsumsi saja, itu pun jika ditanya baru mereka menyampaikan cara penggunaan tersebut" (H.M - Hasil wawancara tanggal 12 November 2019).

Pendapat lain juga mengatakan bahwa:

"Kami selaku petugas di Instalasi Farmasi sangat mudah untuk ditemui, serta memberikan layanan obat juga cepat. Tapi biasanya tergantung juga dari jenis obatnya, kalau obat jadi 15-30 menit sudah ada, kalo racikan biasanya 30 menit lebih.

Tapi kalo banyak pasien biasanya juga menunggu. Untuk penyerahan obat iya kami selaku petugas memberikan obat dengan cara memberitahukan cara mengkonsumsi obatnya, karena itu memang tugas kami selaku petugas di Instalasi Farmasi" (M.I - Hasil wawancara tanggal 12 November 2019).

Hasil wawancara yang dilakukan terhadap informan, mengenai keandalan petugas Instalasi Farmasi RSUD Prof. Dr. H. Aloei Saboe, ditinjau dari aspek pertanyaan tentang: (1) kemudahan petugas untuk ditemui dan dihubungi, (2) Kecepatan dalam memberikan pelayanan, dan (3) Penjelasan petugas mengenai DAGUSIBU, menunjukkan bahwa:

"Petugas instalasi farmasi RSUD Prof. Dr. H. Aloei Saboe mudah untuk ditemui dan dihubungi, berkenaan dengan kecepatan dalam pelayanan terlihat bahwa semuanya tergantung dari jenis obatnya, kalo obat biasa cepat tapi kalau obat racikan biasanya lama sampai 1 jam lebih.

Mengenai cara penggunaan, penyimpanan dan pembuangan petugas hanya menjelaskan tentang cara penggunaan saja, itu pun hanya tertera di plastik yang tertulis $3 x 1$ misalnya”. (R.Z - Hasil wawancara tanggal 12 november 2019).

\section{Dimensi Responsiveness (Tanggap)}

Wawancara yang dilakukan terhadap informan selaku petugas Instalasi Farmasi mengenai dimensi responsiveness (tangap) dengan pertanyaan tentang: (1) sikap petugas instalasi farmasi, (2) informasi jika terdapat keterlambatan penyerahan obat kepada pasien, dan (3) ketepatan waktu dalam memberikan pelayanan obat, menunjukkan bahwa: .

"Sikap petugas dalam memberikan pelayanan kadang-kadang ada yang ramah, bahwa semua tergantung mood" (R.O - Hasil Wawancara Tanggal 11 November 2019).

Wawancara yang dilakukan terhadap informan pasien mengenai dimensi responsiveness (tangap) dengan pertanyaan 
tentang: (1) sikap petugas instalasi farmasi, (2) informasi jika terdapat keterlambatan penyerahan obat kepada pasien, dan (3) ketepatan waktu dalam memberikan pelayanan obat, menunjukkan bahwa:

\begin{abstract}
"Petugas instalasi farmasi hampir semua yang ditempat penerimaan resep ataupun penyerahan resep memiliki sikap yang sopan, ramah terhadap keluarga pasien, itu mungkin dikarenakan mereka sudah dibekali cara memberikan pelayanan publik". (I.Y dan H.M - Hasil Wawancara Tanggal 12 November 2019).

"Pemberian pelayanan obat masih belum tepat waktu, padahal ada standarnya yang dipasang di ruang tunggu untuk obat biasa maksimal 30 menit dan obat racikan maksimal 60 menit. Tapih realitanya bahwa masa tunggu pengambilan obatnya cukup lama lebih dari standar yang ada. Selain itu juga bahwa ketika terjadi keterlambatan petugas tidak memberitahukan kepada keluarga pasien sehingga harus menunggu dengan waktu yang cukup lama, nah pada kondisi tersebut kita sebagai keluarga merasa kejenuhan apalagi tidak ada hiburan yang bisa dilihat. Padahal harusnya petugas memberikan informasi jika masih lama waktu tunggu pengambilan obat, biar kita keluarga mungkin bisa keluar sejenak misalnya untuk mencari makan atau minum" (W.I.A - Hasil

Wawancara Tanggal 12 November 2019).
\end{abstract}

\section{Dimensi Assurance (Jaminan)}

Wawancara yang dilakukan terhadap informan petugas pada Instalasi Farmasi terkait dimensi assurance (jaminan) terhadap pelanggan dengan beberapa pertanyaan berikut: (1) tenaga yang bertugas di instalasi farmasi, (2) perilaku petugas instalasi farmasi dalam memberikan pelayanan, dan (3) biaya pengambilan obat di Instalasi Farmasi untuk umum dan BPJS serta perlakuannya terhadap pasien umum dan BPJS, menunjukkan bahwa:

"Petugas instalasi farmasi menurutnya adalah tenaga apoteker dan tenaga asisten apoteker, tenaga itu terlihat bahwa mereka terlihat menggunakan jas, berarti mengindikasikan mereka adalah tenaga apoteker. Selain itu juga menerangkan bahwa petugas yang memberikan pelayanan memberikan jaminan kenyamanan terhadap saya, disitu terlihat mereka saat menyerahkan obat terlihat sangat sopan, ramah. Dalam pelayanan pun mereka tidak membedakan antara pasien umum dan BPJS karena tidak ada yang menspesialkan kepada kami sebagai keluarga pasien/ pasien, sedangkan kalau biaya misalnya BPJS murah karena tidak bayar kalau umum tidak tahu mungkin mahal". (R.Z - Hasil wawancara tanggal 12 November 2019).
Wawancara yang dilakukan terhadap informan pasien pada dimensi assurance (jaminan) terhadap pelanggan . dengan beberapa pertanyaan tentang: (1) tenaga yang bertugas di instalasi farmasi, (2) perilaku petugas instalasi farmasi dalam memberikan pelayanan, dan (3) biaya pengambilan obat di instalasi farmasi untuk umum dan BPJS serta perlakuannya terhadap pasien umum dan BPJS, menunjukkan bahwa:

"Petugas tidak mengenalkan dirinya sebagai tenaga apoteker atau asisten apoteker, sehingga saya tidak tahu apakah yang melayani saya itu petugas farmasi atau hanya sebagai tenaga administrasi. Namun secara keseluruhan tentang jaminan yang diberikan kepada saya selaku keluarga pasien petugas memberikan jaminan dengan sikap ramah, sopan serta tidak membedabedakan antara pasien Umum dan BPJS”. (R.Z Hasil wawancara tanggal 12 November 2019).

\section{Aspek Empathy (Empati)}

Wawancara yang dilakukan terhadap informan dengan melihat aspek empathy (empati) petugas terhadap keluarga pasien. Dari konteks empati, petugas harus mampu menempatkan dirinya pada pelanggan dapat berupa mudah juga dalam menjalin hubungan dan komunikasi, termasuk perhatiannya terhadap keluarga pasien/pasien. Dalam wawancara ini peneliti memberikan pertanyaan kepada keluarga pasien seperti: (1) ketika keluarga pasien menyerahkan resep atau mengambil obat memberikan salam, senyum, dan sapa. (2) Apakah petugas memberikan respon atau memperhatikan kebutuhan setiap pelanggan, dan (3) apakah petugas dapat memahami perasaan atau kebutuhan dari keluarga pasien/pasien. Berdasarkan wawancara yang dilakukan kepada informan petugas, diketahui bahwa:

"Petugas di bagian loket saat memberikan pelayanan khususnya saat menyerahkan obat tidak memberikan salam terlebih dahulu, yang ada keluarga pasien/pasien lebih duluan yang memberikan salam. Padahal harusnya kalo merujuk pelayanan publik mereka harus memberikan salam dulu, seperti di bank-bank begitu. Dalam hal ini juga menurut saya mereka hanya menanyakan kembali nama pasien saja, mungkin untuk mengonfirmasi kebenaran data yang masuk, tapi kalau untuk menerapkan yang salam, senyum, dan sapa ini belum dilakukan oleh petugas. Sedangkan menurut saya untuk respon terhadap kami selaku pasien masih belum sesuai, kalo untuk memahami kebutuhan kami selaku 
pasien/keluarga pasien belum begitu nampa., Buktinya kita yang lama mengantri ini tidak diberikan fasilitas hiburan atau informasi yang bisa kita lihat saat menunggu" (I.S - Hasil wawancara tanggal 12 November 2019).

\section{PEMBAHASAN}

\section{Dimensi Tangible (Bukti Fisik)}

Tangible atau bukti fisik dapat berupa ketersediaan sarana dan prasarana termasuk di dalamnya adalah alat yang siap pakai serta penampilan petugas yang menyenangkan. Dimensi ini juga dapat gambarkan sebagai kemampuan rumah sakit dalam memberikan atau menunjukkan pelayanan dan eksistensinya kepada pelanggan yaitu keluarga pasien/pasien. Bukti fisik seperti sarana dan prasarana rumah sakit serta keadaan lingkungan di sekitarnya merupakan representasi nyata dari pelayanan yang diberikan oleh pemberi layanan di rumah sakit. Sarana adalah segala sesuatu yang dapat dipakai sebagai alat dalam mencapai maksud atau tujuan, alat, media. Sedangkan prasarana adalah segala sesuatu yang merupakan penunjang utama terselenggaranya suatu proses (usaha, pembangunan, proyek, dan sebagainya) (KBBI, 2007 dalam Evans, 2017).

Hasil penelitian menujukkan bahwa Instalasi Farmasi RSUD Prof. Dr. H. Aloei Saboe, Kota Gorontalo menunjukkan bahwa dari aspek ketersediaan informasi alur layanan pengambilan obat serta lama waktu tunggu telah terpenuhi sesuai dengan standar pelayanan kefarmasian berdasarkan Peraturan Menteri Kesehatan RI No. 73 tahun 2016 tentang Standar Pelayanan Kefarmasian Di Apotek. Mengenai aspek kebersihan ruang tunggu Instalasi Farmasi RSUD Prof. Dr. H. Aloei Saboe, Kota Gorontalo dapat dikategorikan memiliki kebersihan yang sudah baik karena secara berkala petugas kebersihan yang ada mengerjakan pembersihan dan jika melihat kotoran, petugas langsung mengangkat dan membersihkannya. Mengenai aspek bukti fisik lainnya dalam Instalasi Farmasi RSUD Prof. Dr. H. Aloei Saboe, Kota Gorontalo yaitu sarana prasarana penunjang seperti sound system dan TV LED sebagai media informasi. Hasil observasi menunjukkan bahwa terdapat fasilitas sound system dan TV LED namun secara fungsi masih kurang representatif sehingga masih banyaknya keluhan yang disampaikan oleh keluarga pasien.

Hal yang mendasar adalah suara sound system terkadang terdengar keras dan terkadang suaranya kecil begitu pula dengan TV LED yang tidak dapat menyala. Kondisi ini juga dikuatkan oleh kepala instalasi bahwa memang sarana tersebut dalam kondisi yang kurang baik. Selain itu juga bahwa kondisi ruang tunggu instalasi farmasi yang terbuka ini menjadi kelemahan tersendiri. Akses terbuka tersebut dijadikan sebagai akses hilir mudiknya masyarakat umum/pelanggan/ keluarga pasien yang akan menuju ke sentra atau unit lain di rumah sakit. Selaras dengan teori yang dikemukakan oleh Tjiptono pada tahun 2006 dalam Pakpahan 2015 yang menyatakan bahwa dimensi tangible (bukti fisik) harusnya meliputi fasilitas fisik seperti sarana, serta keselarasan antara fasilitas fisik dan jenis layanan yang di berikan kepada pelanggan. Selain itu juga bukti fisik harusnya berupa ketersediaan sarana dan prasarana termasuk alat yang siap pakai (Bustami, 2011).

\section{Dimensi Reliability (Keandalan)}

Reliabilility atau keandalan dalam konteks pelayanan kesehatan di rumah sakit yaitu kemampuan rumah sakit dalam memberikan pelayanan sesuai dengan apa yang dijanjikan dengan akurat dan terpercaya, keharusan dan kesesuaian dengan harapan pasien dalam kinerja yang tepat waktu, sikap simpatik dengan akurasi yang tinggi, serta pelayanan tanpa kesalahan. Hasil penelitian Pada Instalasi Farmasi RSUD Prof. Dr. H. Aloei Saboe, Kota Gorontalo terhadap dimensi keandalan petugas instalasi terhadap kemudahan untuk ditemui oleh pelanggan/keluarga pasien menunjukkan bahwa semua informan menyatakan mudah menemui petugas, karena pada dasarnya semua petugas stand by di loket Instalasi Farmasi. Namun berbanding terbalik dengan kecepatan pemberian pelayanan obat. Hasil yang didapat bahwa pelayanan yang diberikan begitu lamban bahkan tidak sesuai dengan standar yang telah ditetapkan dalam SOP Instalasi Farmasi RSUD Prof. Dr. H. Aloei Saboe, Kota Gorontalo yang mana dituliskan dalam standar tersebut untuk pengambilan obat jadi paling lama 30 menit dan obat racikan selama 60 menit. Sebagian besar pelanggan menyampaikan pelayanan yang diberikan cukup menunggu lama bahkan biasanya sampai lebih dari 60 menit.

Faktor dalam keterlambatan ini menurut informasi dari kepala instalasi laboratorium karena adanya sistem yang sedikit kontradiktif antara instalasi Poli di RSUD Prof. Dr. H. Aloei Saboe, Kota Gorontalo. Instalasi farmasi berusaha membuka loket sesuai standar waktu 
kerja mulai dari jam 08.00 pagi, namun instalasi poli yang ada di rumah sakit membuka loket biasanya pada pukul 09.30 hingga pukul 10.00 . Hal tersebut sangat berpengaruh terhadap pelayanan obat di Instalasi Farmasi, dikarenakan pada saat poli dibuka semua resep tertumpuk begitu banyak. Informasi tersebut setelah dilakukan konfirmasi langsung dan peninjauan langsung oleh peneliti bahwa benar adanya, pelanggan akan tertumpuk diantara jam 10.00 tersebut.

Instalasi Farmasi telah mencoba melakukan dan mengurai kondisi tertumpuknya keluarga pasien dalam pengambilan obat dengan cara membuat skema dan berkoordinasi dengan Instalasi Poli yang ada di rumah sakit, namun hasilnya masih belum maksimal. Menurut kepala instalasi bahwa belum ada sinkronisasi antar sistem yang di bangun. Disamping itu, para dokter di Instalasi Poli melakukan kunjungan pasien sehingga tetap belum bisa memecahkan penumpukan pengambilan obat di waktu tertentu. Namun insiatif dari kepala instalasi dan petugas farmasi jika terjadi penumpukan dan komplain maka keluarga pasien dipanggil untuk diberikan edukasi dan penjelasan tentang keterlambatan dan lama waktu tunggunya.

Fenomena di lapangan menunjukkan bahwa pada dimensi keandalan petugas Instalasi Farmasi terhadap pemberian informasi penggunaan obat, sebagian besar informan menyatakan kepuasannya, karena setiap petugas menyerahkan obat dengan memberikan keterangan dan penjelasan tentang cara penggunaan obat, penyimpanan obat maupun cara membuang pembungkus obat. Cara tersebut sudah sesuai dengan standar pelayanan farmasi di rumah sakit yang dikeluarkan berdasarkan Keputusan Menteri Kesehatan Republik Indonesia Nomor 1197/MENKES/SK/X/2004 pada Bab II tentang Standar Pelayanan Farmasi Rumah Sakit yang menyebutkan bahwa tujuan pelayanan farmasi poin $b$ adalah menyelenggarakan kegiatan pelayanan profesional berdasarkan prosedur kefarmasian dan etik profesi, serta pada poin c yang menerangkan bahwa tujuan pelayanan farmasi adalah Melaksanakan KIE (Komunikasi Informasi dan Edukasi) mengenai obat. Sehingga simpulan akhir pada dimensi keandalan dapat dinyatakan bahwa kualitas pelayanan yang diberikan oleh petugas kepada pelanggan/keluarga pasien dapat dinyatakan sudah sesuai dengan standar dan harapan pelanggan.

\section{Dimensi Responsiveness (Tanggap)}

Responsiveness atau ketanggapan merupakan suatu keinginan ataupun kemauan untuk memberikan pelayanan cepat dan tepat kepada keluarga pasien dalam menghadapi permintaan, pertanyaan, keluhan, dan masalah dari keluarga pasien serta memberikan perhatian yang penuh terhadap keluarga pasien. Pada dimensi ketanggapan ini merefleksikan komitmen perusahaan atau instansi untuk memberikan pelayanan yang tepat pada waktunya dan persiapan instansi sebelum memberikan pelayanan kepada pelanggan (Bustami, 2011). Dalam konteks ketanggapan ini juga termasuk dalam hal membiarkan pasien menunggu tanpa adanya alasan yang jelas, maka ini dapat menyebabkan persepsi yang negatif dalam kualitas pelayanan (Mulyadi, dkk. 2013). Hasil penelitian ini menunjukkan bahwa petugas Instalasi Farmasi telah memiliki kemampuan dalam memberikan layanan kepada pelanggan dengan bersikap ramah dan sopan. Hal ini juga terlihat jelas bahwa keluarga pasien mengalami kepuasan tersendiri terhadap sikap ramah dan sopan dari petugas Instalasi Farmasi. Ini jelas bahwa petugas Instalasi Farmasi mempertimbangkan kode etik keprofesian dan sesuai dengan tugas pokok dan fungsi dari tugas kefarmasian seperti yang tertuang dalam Standar Pelayanan Farmasi Rumah Sakit berdasarkan Permenkes Nomor 1197/MENKES/SK/X/2004.

Kualitas layanan yang diberikan petugas Instalasi Farmasi kepada keluarga pasien ditinjau dari aspek ketanggapan petugas instalasi dinilai baik dan memenuhi standar yang telah ditetapkan

\section{Dimensi Assurance (Jaminan)}

Hasil penelitian menunjukkan bahwa petugas yang berada di instalasi tidak semuanya tenaga kefarmasian dengan komposisi yang ada di instalasi adalah 4 tenaga apoteker, 8 tenaga asisten kefarmasian, dan 3 tenaga administrasi. Kendala SDM pada Instalasi Farmasi yaitu masih ada tenaga di Instalasi Farmasi yang hanya lulusan SMA. Hal ini dikarenakan mereka merupakan tenaga abdi/ honorer yang telah diangkat menjadi Aparatur Sipil Negara dan sudah lama mengabdikan dirinya. Melihat fenomena tersebut pemenuhan SDM yang profesional sebenarnya tidak sesuai dengan kebutuhan dari instalasi itu sendiri. Faktor SDM ini terkonfirmasi seperti yang disampaikan oleh keluarga pasien yang menyatakan bahwa saat 
memberikan pelayanan petugas tidak menginformasikan identitas dirinya atau memperkenalkan dirinya. Perilaku tersebut secara emosional belum dapat memberikan kepuasan serta kualitas tersendiri yang didapatkan keluarga pasien jika petugas tidak memberikan informasi kepada keluarga pasien karena dapat berkaitan dengan jaminan rasa aman yang diberikan. Kualitas pelayanan yang diberikan harus memenuhi unsur kesesuaian dengan persyaratan/tuntutan (Tjiptono, 2004 dalam Pakpahan, 2015). Disamping itu, dalam hal kenyamanan, petugas memberikan rasa aman dengan cara memberikan sikap yang sopan, ramah, serta hormat terhadap pelanggan. Perilaku tersebut menutupi kekurangan pada komunikasi awal, selain itu juga bahwa petugas Instalasi Farmasi tidak membeda-bedakan keluarga pasien/pasien dari BPJS maupun pasien dari umum. Semua dalam perlakuan yang sama melalui satu sistem yaitu nomor antrian. Hal tersebut menunjukkan bahwa keadilan yang diberikan Petugas Instalasi Farmasi RSUD Prof. Dr. H. Aloei Saboe, Kota Gorontalo sudah baik sesuai dengan cara memberikan pelayanan kepada keluarga pasien. Indikator yang telah dilakukan dan diberikan dengan baik tersebut menjadikan pelayanan yang dilakukan oleh petugas berjalan dengan baik dan lancar. Sikap ramah, sopan, dan menghargai keluarga pasien yang diberikan oleh petugas Instalasi Farmasi membuat rasa aman dan nyaman kepada keluarga pasien/pasien, maka disimpulkan dimensi assurance pada kualitas pelayanan kesehatan di Instalasi Farmasi rumah sakit dinyatakan baik. SDM merupakan suatu faktor yang sangat penting dalam sebuah organisasi, bahkan tidak dapat dilepaskan dalam konteks organisasi pemerintahan maupun non pemerintahan serta dalam konteks pelayanan kesehatan maupun non kesehatan. Hakikatnya SDM adalah berupa manusia yang dipekerjakan dalam sebuah institusi/ perusahaan/ organisasi sebagai motor penggerak, pemikir serta sebagai perencana dalam mencapai tujuan dari organisasinya (Greer, 2012 dalam Mukarom 2015).

\section{Dimensi Emphaty (Empati)}

Hasil penelitian bahwa petugas Instalasi Farmasi masih belum dapat merasakan apa yang dirasakan oleh pasien/keluarga pasien. Pasien/keluarga pasien merupakan customer yang secara psikologis mengalami tekanan atau penuh kekhawatiran, sehingga harapan yang diinginkan dalam pemberian pelayanan sebisa mungkin memberikan pelayanan yang berkualitas dan memuaskan. Dalam hal ini tinjauan peneliti melihat pada konteks dasar pada sikap petugas tentang konsep 5S (salam, senyum, sapa, sopan, dan santun). Tinjauan ini digunakan untuk mengukur seberapa besar sikap petugas dalam memberikan pelayanan yang baik kepada pasien/ keluarga pasien. Seperti hasil yang peneliti dapatkan bahwa pernyataan dari kepala instalasi menyampaikan bahwa budaya 5S merupakan keharusan yang harus dilakukan oleh para petugas karena merupakan dasar pelayanan untuk memberikan rasa empati kepada keluarga pasien/pasien.

Fenomena yang terjadi dalam penelitian ini yaitu petugas belum menerapkan budaya $5 \mathrm{~S}$ secara baik. Hal ini jelas tergambarkan berdasarkan hasil wawancara terhadap keluarga pasien/pasien yang menyatakan bahwa petugas tidak memberikan salam, senyum, dan sapa. Sebaliknya yang sering terjadi adalah keluarga pasien terkebih dahulu yang memberikan salam bahkan senyuman tidak ditampakkan oleh petugas. Sebagai masyarakat yang berada di kawasan timur dengan budaya keramahan, arti salam dan senyum memberikan makna yang cukup besar terhadap perilaku yang diberikan pelayanan. Hasil tersebut dikuatkan juga oleh kepala instalasi bahwa memang benar kekurangan di Instalasi Farmasi masih ada oknum petugas yang masih belum menerapkan salam, senyum, dan sapa kepada keluarga pasien/pasien.

Hasil penelitian dalam masa tunggu yang lama juga mempengaruhi terhadap kualitas pelayanan, dengan hasil tersebut bahwa ada perasaan kurang empati atau kurang merasakan apa yang dirasakan oleh pasien/keluarga pasien. Komunikasi yang baik perlu terjalin dengan baik kepada pasien/keluarga pasien, pasalnya pasien/keluarga pasien merupakan customer yang harus mendapatkan pelayanan yang berkualitas. Sehingga dapat disimpulkan bahwa kualitas pelayanan kesehatan di Instalasi Farmasi RSUD Prof. Dr. H. Aloei Saboe, Kota Gorontalo ditinjau dari dimensi empati petugas masih kurang memuaskan bagi pasien/keluarga pasien.

Berdasarkan uraian pembahasan diatas maka harapan dari pasien/keluarga pasien adalah terciptanya pelayanan yang berkualitas sehingga memberikan nilai kepuasan tersendiri bagi pasien/keluarga pasien. Pelayanan yang diberikan secara menyeluruh di Instalasi Farmasi 
sudah dapat dinyatakan cukup baik. Hal ini tergambarkan Instalasi Farmasi mencoba mendesain dan melaksanakan proses pelayanan secara maksimal dengan memberikan apa yang dibutuhkan oleh pasien/keluarga pasien. Walaupun fenomena yang terjadi masih terlihat nampak beberapa kekurangan dari pelayanan yang diberikan. Di samping itu, pasien memiliki harapan dan keinginan terhadap pelayanan kesehatan yang baik melalui semua keinginan pasien/keluarga pasien terpenuhi agar perasaan pasien/keluarga pasien menjadi lebih enak dan secara psikologis dapat memberikan dampak dalam percepatan dalam penyembuhan penyakitnya. Sedangkan menurut para petugas kesehatan khususnya di instalasi farmasi bahwa pelayanan yang diberikan sudah sesuai standar yang telah ditetapkan. Perbedaan persepsi ini bisa timbul, karena secara teoritis yang dikemukakan oleh menerangkan bahwa pelayanan kesehatan memiliki keunikan tersendiri dibandingkan dengan pelayanan publik lainnya, antara lain yang dimaksudkan adalah bersifat asymetri of information yang berarti bahwa konsumen pada pelayanan kesehatan berada pada posisi yang lemah serta kurang memiliki pengetahuan serta infromasi tentang alur dan sistem pelayanan yang diberikan. Sedangkan provider dalam hal ini adalah petugas kesehatan mengetahui jauh lebih banyak tentang kualitas pelayanan kesehatan tersebut (Evans, 2007).

\section{KESIMPULAN DAN SARAN}

\section{Kesimpulan}

Kualitas pelayanan kesehatan di Instalasi Farmasi RSUD Prof. Dr. H. Aloei Saboe, Kota Gorontalo dilihat dari 5 dimensi yaitu Tangible, Relianbility, Responsiveness, Assurance, dan Emphaty menunjukkan bahwa Instalasi Farmasi masih dipandang kurang oleh customer sehingga perlu untuk meningkatkan kualitas pelayanannya terutama pada dimensi tangible (bukti fisik) dan emphaty (empati). Sedangkan dimensi relianbility (keandalan), responsiveness (tanggap), dan assurance (jaminan) dipandang cukup namun tetap harus meningkatkan kualitas SDM yang merupakan motor penggerak organisasi karena masih belum memiliki kompetensi pendidikan yang sesuai berdasarkan persyaratan perundang-undangan.
Saran yang dapat diberikan kepada manajemen RSUD Prof. Dr. H. Aloei Saboe, Kota Gorontalo yaitu: (1) lebih memperhatikan sarana penunjang seperti penambahan kipas angin diruang tunggu instalasi farmasi, mengaktifkan kembali TV LED yang digunakan sebagai sumber informasi pasien/keluarga pasien, memperbesar jangkauan sound system. (2) Jalur evakuasi untuk pasien ke instalasi yang lain sebaiknya tidak disatukan dengan bagian ruang tunggu pasien/ keluarga pasien. (3) Penambahan dan peningkatan Kualitas SDM yang relevan sesuai bidang ilmu yaitu kefarmasian, sehingga dengan kapasitas SDM yang memadai ini dapat memberikan layanan yang cepat sesuai dengan harapan pasien/keluarga pasien.

\section{DAFTAR RUJUKAN}

1] Azwar, A., 2015. Menjaga Mutu Pelayanan Kesehatan. Jakarta: Pustaka Sinar Harapan.

2] Bustami, 2011. Penjaminan Mutu Pelayanan Kesehatan dan Akseptabilitasnya. Jakarta: Erlangga.

3] Evans, R., 2007. The Economic of Canadian Health care. Toronto: Butterworths.

4] Fahmi, A., 2016. Analisis Penyebab Rendahnya Budaya 3S Pada Karyawan Rumah Sakit XYZ. Jurnal Kesehatan, pp. 24-35.

5] Hidayatullah, F., 2010. Pendidikan Karakter membangun Peradaban bangsa. Surakarta: Yuma Pustaka.

6] Keputusan Menteri Kesehatan RI Nomor 1197/MENKES/SK/X/2004, 2004. Tentang Standar Pelayanan Farmasi Rumah Sakit Indonesia,

7] Mukarom, Z., 2015. Manajemen Pelayanan Publik. Bandung: Pustaka Setia.

8] Mulayadi, D., Fadli, U. \& Kusuma, F., 2013. Analisis manajemen Mutu Pelayanan Kesehatan Pada Rumaha Sakit Islam Karawang. Jurnal Manajemen, pp. 19-30.

9] Pakpahan, S., 2015. Pelayanan Prima. Artikel Ilmiah Rumah Sakit, pp. 15-25.

\section{Saran}

